\author{
ALEKSANDRA WACH \\ Uniwersytet im. Adama Mickiewicza w Poznaniu
}

\title{
Classroom-based language efficiency assessment: a challenge for EFL teachers
}

\begin{abstract}
This paper attempts to highlight the significant multidimensional role of teachers of English as a foreign language in conducting language assessment in the process of teaching. The study presented in the article aimed to investigate school and university EFL teachers' $(n=87)$ beliefs about the place of assessment in their teaching practice and their role as assessors. The findings indicated that classroom assessment, though appreciated by the study participants, posed a major challenge to them.
\end{abstract}

KEYWORDS: language assessment, teacher assessment, teachers' beliefs, teacher as assessor.

\section{INTRODUCTION}

The multiple functions that assessment performs in the process of teaching should not be underestimated. Rea-Dickins (2004: 249) starts her article with a straightforward and powerful statement: "[ $\mathrm{t}$ ]eaching involves assessment". Cheng, Rogers and $\mathrm{Hu}$ (2004) contend that in every instructional model vital decisions concerning the selection of teaching approaches and procedures are based on some kind of evaluation of learners' progress. In the process of implementing instructional procedures, teachers constantly acquire information about learners' attainment, their strengths and weaknesses. Hence, many researchers (Genesee and Upshur 1996; Komorowska 2002; Rea-Dickins 2004; 2006; Black 2009; Falsgraf 2009) highlight the constant interaction between teaching, assessment and learning. As emphasized by the current literature on the subject (e.g. Fulcher, Davidson 2007; Llosa 2011), assessment is generally acknowledged to be one of the most central issues in contemporary language education. In this article, after a brief di- 
scussion of the position of assessment in teaching based on the literature of the subject, the findings of a study aimed at ascertaining EFL teachers' beliefs about classroom-based assessment will be presented.

\section{FOREIGN LANGUAGE TEACHERS' INVOLVEMENT IN LANGUAGE ASSESSMENT}

Cumming (2009) stresses the complexity of teachers' role as assessors: most language teachers are routinely expected to respond purposefully to their students' written and oral communication, report on subsequent achievements of individual students in their courses, diagnose individual learning challenges or problems, determine student groupings for placements or learning tasks; evaluate in an informed manner test instruments for their validity and suitability, and interpret and apply, often in collaboration with other teachers, curriculum policies based on benchmark standards or criteria. As stressed by Piegzik (2005), assessment is equally important to the teacher and the learner, as it contributes to the efficiency of both teaching and learning. Emphasizing the huge role of teachers in making assessment become a vital part of learning, Rea-Dickins (2004) refers to them as "agents" of assessment, in that they routinely observe, evaluate and interpret students' performance in order to enhance their learning outcomes. In a similar vein, Brown (2004) compares them to "tennis coaches", who are constantly monitoring students' performance. Classroom-based assessment which accompanies learners' progress is mostly formative in nature, however, as ReaDickins (2004) notes, teachers themselves tend to perceive assessment in more formal, proceduralized terms - a view derived from the focus on language proficiency testing predominant in research and publications. ReaDickins (2004) and Czetwertyńska (2005) also suggest that teachers may feel uncomfortable in the situation of what they see as competing demands, namely to function as a facilitator of students' efforts to learn a foreign language, but also as a judge of learner performance.

Leung (2005) acknowledges the significant involvement of the teacher in the different types of assessment, most of which overlap and influence each other, such as authentic, formative and informal assessment. She makes the point that because of its informative value and local dimension, "teacher assessment" that incorporates elements of these kinds of assessment should become a substantial part of standardized testing.

Poehner (2009) and Lantolf (2009) highlight the central role of the teacher in dynamic assessment, in which the teacher offers constant mediated assistance during interactions that provide assessment opportunities and pro- 
mote learning. Poehner (2009: 417) explains that in this kind of assessment the teacher's task is not merely to observe their students' progress, but it is based on a model "in which teachers and students jointly carry out activities, with teachers intervening as necessary to help learners stretch beyond their current capabilities". This approach demands that teachers simultaneously adopt dual roles: that of instructor and of assessor. Moreover, Zawadzka (2004: 244-245) and Bullock (2011: 115-116) discuss the role of the teacher in encouraging learner self-assessment, which is crucial in the development of learner autonomy, while Mok (2011) concentrates on peer assessment, which is another recent alternative to typical teacher assessment and demands the assumption of new roles by students and teachers.

Cheng et al.'s (2004) study findings reveal the significant role of teachers' beliefs and attitudes toward assessment in the methods and procedures undertaken by them in the practice of evaluating their students. These beliefs and attitudes are, in turn, largely dependent, apart from other factors, on the particular social and cultural context in which the learning-teaching process takes place.

\section{LANGUAGE ASSESSMENT RESEARCH}

As Bachman (2008) notes, language assessment is a dynamically developing field of empirical enquiry, constantly broadening its scope of investigation and repertoire of research methods and tools. The measurement of learners' progress and language ability, and the validity of the interpretations of research data are still at the heart of assessment research, with additional dimensions having recently been added, such as the role of the sociocultural context of assessment and the way this influences its purposes and procedures, as well as the ethical issues involved in assessment (e.g. McNamara and Roeven 2006).

According to Rea-Dickins (2006), research on assessment has been conducted from five broad perspectives. One of these encompasses investigations into the influence of formal examinations on classroom instruction: on the content of curricula, on teacher pedagogy, etc. Another one focuses on the links between authenticity and congruence of assessment and particular teaching programs. The following research perspective investigates the success of a language program in terms of learner attainment. The fourth and the fifth perspectives focus on instruction-based formative dimension of assessment and learners' involvement in it.

Leung and Lewkowicz (2006) note that apart from considerations concerning the design and administration of large-scale certificate testing, scho- 
$\mathrm{ol}$ and classroom-based assessment is increasingly the focus of researchers' attention, although Rea-Dickins (2004) and Cheng et al. (2004) complain that this dimension of assessment has not yet been adequately embraced by research. Similarly, Davison and Leung (2009) admit that teacher-based assessment of English as a second/foreign language has been largely neglected by research, in contrast to the amount of such research into the teaching of other school subjects.

\section{THE STUDY}

\subsection{Objectives}

The most prominent aim of the study was to learn about the beliefs and perceptions of teachers of English concerning the relevance of language assessment and the challenges it poses to teachers. Moreover, the study aimed to investigate differences between teachers from different educational levels (more specifically, university teachers and school teachers) in the way they approach assessment and evaluate its strengths and the possible problems involved in it. Finally, the study was expected to highlight differences between native-speaker and non-native-speaker (Polish) teachers of English at the university level concerning assessment-related beliefs.

\subsection{Organization and procedure}

The study was conducted on 87 teachers of English as a foreign language. Within the sample, two different groups were differentiated: one was constituted by university teachers ( $n=42$, with 12 native-speaker teachers and 30 nonnative-speaker teachers), who taught English to advanced learners, English majors in the same institution, while the other group was comprised of 45 school teachers who taught EFL at different kinds of schools: primary $(n=17)$, middle $(n=20)$, and secondary $(n=8)$, at different levels of language proficiency, ranging from elementary to intermediate, and in different places in Poland. The teaching experience of the total sample ranged from 0.5 to 30 years. It seems relevant to note here that while the school teachers had to give grades to their students as part of their administrative duty, there was no such obligation in the case of the university teachers, who decided whether they wanted to formally assess their students' progress in the form or grades or not.

The tool used for data collection was a questionnaire which consisted of both open-ended and closed-ended items and which yielded both qualita- 
tive and quantitative data. The questionnaire was administered to the university teachers as part of an ELT a workshop in which they participated, and to the school teachers before a lecture on language assessment which was part of a professional development session organized by an AmericanPolish Foundation.

\subsection{Findings}

The initial question in the questionnaire was: "Do you assess your students?". Not surprisingly, almost all the respondents provided positive answers (all 45 school teachers and 39 out of the 42 university teachers). One university teacher provided a negative answer, and the 2 remaining ones opted for "other answers", which were formulated by the teachers as "Sometimes" or "It depends". Both of these "other answers" in fact indicated that the teachers assessed their students, although perhaps they perceived their assessment procedures as less systematic.

The following question concerned the reasons why the respondents assessed their students. The multitude of answers generated were subsequently grouped by the researcher into three categories: student/learningoriented purposes, teacher/teaching-oriented ones, and finally, administration-oriented reasons. A number of valid reasons were provided within the student/learning-orientation, although it needs to be noted that while the school teachers mainly concentrated on just two general reasons, namely the provision of feedback on the students' performance or progress and its motivating function, the university teachers, apart from these two purposes, came up with a whole list of specific learner-centered reasons for assessment, for example: "to give them a feeling of achievement"; "to help them correct their mistakes and improve accuracy"; "to let them realize how they perform"; "to make them see that I care for them and for what they do"; "because they expect it".

Similarly, a large collection of teacher/teaching-oriented reasons for assessment was provided by the respondents, and here no major differences were recorded between the two groups of teachers within the scope of the responses, although it needs to be admitted that the university teachers generally contributed a larger number of more specific reasons within all three categories. The most frequently provided teaching-centered reasons were: "to check progress"; "to check whether they work systematically"; "to be able to plan future work better"; "to try to identify and solve problem areas"; "to check my own effectiveness as a teacher"; "to get to know the students better". Moreover, a reason recurrently given by the school teachers but not the university teachers was "to discipline the students". 
Comparatively fewer reasons were provided within the administrationoriented category, and most of these concerned the need to give grades or credit at the end of the term: "because they make me"; "to give them an idea of what to expect during the exams"; "because of credit requirements / to give grades at the end of the term"; "to inform the students' parents" (this reason was given by school teachers).

The following question focused on the areas which the participants assessed in their teaching practice. The responses given by the teachers are presented in Table 1 and the most frequent ones are highlighted.

Table 1. The areas of assessment provided by the respondents

\begin{tabular}{|c|c|c|c|c|c|c|}
\hline \multirow{3}{*}{ Assessment area } & \multicolumn{2}{|c|}{ School Ts $(n=45)$} & \multicolumn{4}{|c|}{ University Ts $(\mathrm{n}=42)$} \\
\hline & \multirow{2}{*}{$\mathrm{n}$} & \multirow{2}{*}{$\%$} & \multicolumn{2}{|c|}{ NS $(n=12)$} & \multicolumn{2}{|c|}{ NNS $(n=30)$} \\
\hline & & & $\mathrm{n}$ & $\%$ & $\mathrm{n}$ & $\%$ \\
\hline Grammar & 34 & 76 & 4 & 33 & 25 & 83 \\
\hline Vocabulary & 27 & 60 & 5 & 41 & 18 & 60 \\
\hline Pronunciation & 2 & 4 & - & - & 19 & 63 \\
\hline Fluency & - & - & 1 & 8 & 4 & 13 \\
\hline Structure & - & - & 3 & 25 & 2 & 7 \\
\hline Speaking skills & 34 & 76 & 2 & 17 & 5 & 17 \\
\hline Writing skills & 28 & 62 & 3 & 25 & 6 & 20 \\
\hline Reading skills & 31 & 69 & - & - & - & - \\
\hline Listening skills & 28 & 62 & - & - & - & - \\
\hline Content & - & - & 4 & 33 & 2 & 7 \\
\hline Logic & - & - & 1 & 8 & 2 & 7 \\
\hline Creativity & - & - & - & - & 2 & 7 \\
\hline Critical thinking & - & - & 2 & 17 & - & - \\
\hline Class participation & 4 & 9 & - & - & 2 & 7 \\
\hline Exam-related skills & - & - & 2 & 17 & - & - \\
\hline
\end{tabular}

As can be seen from Table 1, grammar was the most frequently listed item, especially by the Polish teachers $(76 \%$ of the school teachers, $83 \%$ of the Polish university teachers and $33 \%$ of the native-speaker university teachers indicated it), followed by vocabulary (provided by $60 \%$ of the school teachers, $60 \%$ of the Polish university teachers and $41 \%$ of the native-speaker teachers). For school teachers, assessing speaking skills was as frequently mentioned as assessing grammar, while for Polish university teachers, pronunciation was high on the list, as $63 \%$ of them said they assessed it. Gene- 
rally, the school teachers provided fewer assessment areas than the university teachers, and their answers included more predicable and more obvious areas of language proficiency: grammar, vocabulary and the four communicative skills, with few teachers mentioning pronunciation and class participation ( 2 and 4 out of the 45 teachers, respectively). It was the university teachers (though few of them) who mentioned less tangible, more specific areas of assessment, such as content, logic, creativity and critical thinking. Interestingly, the university teachers stressed the assessment of their students' knowledge of the system (grammar, vocabulary and pronunciation) more heavily than the development of their communicative skills, while for the school teachers the frequency of mentioning both the system (apart from pronunciation) and the four communicative skills was rather equal. Moreover, the findings suggest that the Polish teachers assessed the knowledge of the language system considerably more that the native-speaker teachers, which may reflect the cultural or attitudinal differences and at the same time differences in the components taught by particular teachers. What the respondents admitted to assessing probably reflected what they focused on in their teaching.

The following question was: "If you give grades in the form of numbers or letters, is it easy or difficult to decide on a grade? Why?". The responses with regard to the ease of difficulty of giving grades are presented in Table 2 and the most frequent answers are highlighted.

Table 2. The ease or difficulty of deciding on a grade

\begin{tabular}{|l|c|c|c|c|c|c|}
\hline \multirow{2}{*}{ Answer } & \multicolumn{2}{|c|}{ School Ts $(\mathrm{n}=45)$} & \multicolumn{4}{c|}{ University Ts (n=42) } \\
\cline { 2 - 7 } & \multirow{2}{*}{$\mathrm{n}$} & \multirow{2}{*}{$\%$} & \multicolumn{2}{c|}{$\mathrm{NS}(\mathrm{n}=12)$} & \multicolumn{2}{c|}{ NNS (n= 30) } \\
\cline { 4 - 7 } & & & $\mathrm{n}$ & $\%$ & $\mathrm{n}$ & $\%$ \\
\hline Easy & 8 & 18 & $\mathbf{1 2}$ & 100 & 12 & $\mathbf{4 0}$ \\
\hline Difficult & $\mathbf{2 6}$ & $\mathbf{5 8}$ & - & - & 10 & 33 \\
\hline Other answers & 11 & 24 & - & - & 8 & 27 \\
\hline
\end{tabular}

An obvious difference between school and university teachers is that while for the majority of the former deciding on a grade was difficult (58\%), for most of the latter it was easy $(100 \%$ native-speaker and $40 \%$ Polish teachers). At the same time, only $8(18 \%)$ school teachers admitted that deciding on a grade was easy for them. This finding may seem surprising, since school teachers usually operate within a well defined assessment system, practically absent at the university level. Moreover, assessing advanced learners (university students) may appear to be particularly challenging, as it necessarily involves a multitude of complex factors (cf. Shohamy and Inbar 2006; 
Shohamy et al. 2008). On the other hand, this finding may imply that the university teachers applied their own, well established criteria for giving grades and therefore managed the process more efficiently. Another reason for the university teachers' ease of deciding on a grade may be connected with the fact that the proficiency level of their students was more uniform. Two teachers saw a relationship between their experience and the ease of giving grades: "It's easy because of my experience"; "The more I teach, the easier it becomes." However, such a correlation was not revealed by the study findings; for two of the most experienced teachers (with more than 20 years' experience) giving grades was still problematic, whereas a number of inexperienced teachers ranked it as easy.

As the data in Table 2 indicate, a substantial number of the respondents ticked the "other answers" option (24\% of the school teachers and $27 \%$ of the university teachers), providing a justification for why it is hard to say whether giving grades is either easy or difficult. Some of the comments were: "It's difficult in assessing content, e.g. interesting ideas and poor language"; "It depends on the component - how 'tangible' it is". It can be inferred from these comments that for the respondents giving grades was a dynamic process, different in the case of different tasks or assessment areas. This points to the fact that giving grades, often a vital part of assessment, poses a challenge to teachers because of the variety of factors involved in language assessment in contemporary didactics. It also reveals the participants' sensitivity to assessment-related issues.

The final two questions were open-ended and asked about the respondents' beliefs regarding the strengths of assessment and the problems involved in it. A large number of comments were obtained. The most frequently listed strong points and challenges of assessment are presented in Tables 3 and 4 .

Table 3. Strong points of assessment listed by the subjects of the study

\begin{tabular}{|l|l|}
\hline \multicolumn{1}{|c|}{ School teachers } & \multicolumn{1}{|c|}{ University teachers } \\
\hline $\begin{array}{l}\text { It motivates students to work, } \\
\text { It gives students and the teacher informa- } \\
\text { tion about their progress, } \\
\text { It gives a solid structure to the course, } \\
\text { helps establish routine. }\end{array}$ & $\begin{array}{l}\text { Students get constructive feedback on their } \\
\text { work, } \\
\text { Information for the students and the teacher, } \\
\text { Appropriate assessment enhances students' } \\
\text { motivation / sense of achievement, } \\
\text { Mapping the students' problems and working } \\
\text { on them / setting directions for future work, } \\
\text { The teacher can evaluate his/her effectiveness, } \\
\text { Opportunities for 'recycling' the material, } \\
\text { It introduces clear rules to the teaching process. }\end{array}$ \\
\hline
\end{tabular}


It is interesting to note that the school teachers could see considerably fewer strong points of assessment than the university teachers and fewer than the problems they were aware of. Primarily, the strong points listed by the school teachers revolved around three relevant functions of assessment: the motivating function, the feedback-providing one and the organizational one. The university teachers, apart from these three points, mentioned the formative dimension of assessment in assisting and enhancing the students' progress and the constructive washback effect.

Table 4. Problems involved in assessment listed by the participants of the study

\begin{tabular}{|c|c|}
\hline School teachers & University teachers \\
\hline $\begin{array}{l}\text { It's not objective, } \\
\text { It's stressful for the learners, } \\
\text { Poor grades are discouraging to the learners, } \\
\text { The lesson is too short, } \\
\text { It's really problematic with young children, } \\
\text { "Difficult" students and parents, who qu- } \\
\text { estion my grades, } \\
\text { I have a problem with assessing dyslexic } \\
\text { students, } \\
\text { It's really difficult in mixed-ability classes, } \\
\text { The range of grades }(1-6) \text { is too limited and } \\
\text { not sensitive enough, } \\
\text { Students cheat in tests. }\end{array}$ & $\begin{array}{l}\text { It's difficult to be objective, } \\
\text { "Emotional luggage": it's easy to hurt stu- } \\
\text { dents' feelings, } \\
\text { Demotivating students, unfairness, permis- } \\
\text { siveness, } \\
\text { Students' performance depends on different } \\
\text { factors: the weather, their condition on a gi- } \\
\text { ven day, etc., } \\
\text { The conflict between course assessment and } \\
\text { exam results, } \\
\text { It's the only thing students are interested in, } \\
\text { Paperwork, time-consuming, } \\
\text { Polish students are over-reliant on tests as } \\
\text { a means of making them study. At this level, } \\
\text { they should have developed their own means } \\
\text { of studying, } \\
\text { My students' English is often better than } \\
\text { mine - how can I assess them? }\end{array}$ \\
\hline
\end{tabular}

The list of challenges posed by assessment, presented in Table 4, is, in the case of both groups of the respondents, longer than the list of its strong points. Apparently, the difficulty of being objective turned out to be the most problematic aspect of assessment, followed by the emotional load (the learners' anxiety, negative feelings) that this necessarily implies. In this situation, instead of being motivating, assessment easily becomes a demotivating factor. The school teachers strongly highlighted the practical issues which make effective assessment difficult, such as the grading system, the length of lessons, the necessity to deal with special needs learners, or students' cheating, which is a serious problem in Polish schools. Taking into account the practical side of assessment, the university teachers voiced their concern with the necessary paperwork, although school teachers' obligations 
are much more demanding in this respect. Some of the respondents mentioned the conflict between formative and summative assessment (i.e. regular classes and examinations) as a source of students' frustration. Moreover, the negative washback phenomenon was mentioned by the university teachers who complained that the students are often preoccupied with grades, which may negatively influence the learning-teaching process. Finally, one Polish university teacher expressed her doubt whether her qualifications are sufficient to enable her to assess her advanced students.

\subsection{Analysis and discussion}

The findings of the study, while casting light on teachers' beliefs about the position and role of assessment in the process of teaching English as a foreign language, seem to reveal the delicate and increasingly complex nature of assessment in contemporary language didactics. It was evident from the participants' responses that they seemed to appreciate the huge role and power of assessment, as practically all of them admitted to assessing their students, and generally they were able to list a variety of assessment purposes which are reflected in their teaching. It may be implied, therefore, that a majority of the teachers realized the multifaceted functions of assessment. At the same time, it needs to be noted that the university teachers seemed to be more aware of the different functions of assessment than the school teachers, which may be interpreted as a consequence of university teachers' greater freedom in choosing different assessment procedures and adjusting them to the students' needs. Moreover, teaching advanced learners may stimulate the teachers to constantly look for new solutions in order to cater to the demanding teaching context.

Similarly, probably for the same reasons, the university teachers provided more assessment areas than the school teachers. In both groups, however, there appeared to be more focus on assessing the more "tangible" elements of the language system, such as grammar and vocabulary. The native-speaker teachers seemed to differ from Polish teachers in this respect - there was considerably more focus on the assessment of the language system among Polish than native-speaker teachers.

Although a multitude of assessment purposes were listed, a general conclusion emerges from the study that many of the teachers perceived teaching and assessment as two separate entities; for example, when providing the obstacles to effective assessment, some of the respondents mentioned the insufficient amount of time in lessons. Much in the same vein, some teachers associated the term "assessment" with giving grades. These findings point to 
a vital conclusion that the summative dimension of assessment was ingrained in the teachers' minds rather than a balance of summative and formative assessment.

An important finding of the study is that giving grades is not necessarily perceived as easy and perhaps it is less straightforward nowadays than it used to be. It may be inferred from the respondents' comments that they seemed to realize the great need for reflection that the process of assessment stimulates. Giving grades, although in most educational contexts inevitable for administrative reasons, needs to be viewed as just one of many forms of assessment in the contemporary classroom.

The list of the strong points of assessment and the problems involved in it makes it clear that assessment poses a serious challenge to teachers. Being a powerful tool of motivating students, providing useful feedback and contributing to an efficient organization of the teaching process, it may, at the same time, turn out to be a source of deep frustrations and demotivation.

\section{CONCLUSIONS}

Although the limited scope of the study allows for no generalizations, some suggestions may be formulated on the basis of teachers' beliefs about assessment presented above. One of them is that teachers need to be made more aware, perhaps at the level of teacher training and development, of the new multifaceted roles of assessment and its different forms, with special emphasis on formative assessment. Consequently, students themselves need to be made aware of the different forms of assessment and should definitely be involved in the process. Another suggestion is that nowadays, when the focus of instruction should be on the leaner, the different forms of alternative assessment need to become an integral part of teaching, replacing or at least co-existing with traditional forms of assessment. A final conclusion emerging from the study findings is that of the large number of roles that the teacher performs in the contemporary foreign language classroom, the role of assessor is probably among the most challenging ones. It takes a considerable level of awareness, organizing skills, expertise and finally, human sensitivity, to successfully carry out the dual roles of instructor and assessor.

\section{REFERENCES}

Bachman, L. F., 2008. Language assessment: opportunities and challenges. Retrieved from the Web Oct 27, 2008, <http://www.aaal.org/index.php?id=48>.

Black, P., 2009. Formative assessment issues across the curriculum: the theory and the practice. In: TESOL Quarterly 43/3, 519-524. 
Brown, H.D., 2004. Language Assessment. Principles and Classroom Practices. New York: Pearson Education.

Bullock, D., 2011. Learner self-assessment: an investigation into teachers' beliefs. In: ELT Journal 65/2, 114-125.

Cheng, L., Rodgers, T., Hu, H., 2004. ESL/EFL instructors' classroom assessment practices: purposes, methods, and procedures. In: Language Testing 21/3, 360-389.

Cumming, A., 2009. Language assessment in education: tests, curricula, and teaching. In: Annual Review of Applied Linguistics 29, 90-100.

Czetwertyńska, G., 2005. Konstruktywizm a ocenianie kształtujące. In: Języki Obce w Szkole 6/2005, 16-19.

Davison, C., Leung C., 2009. Current Issues in English Language Teacher-Based Assessment. In: TESOL Quarterly 43/3, 393-415.

Falsgraf, C., 2009. The ecology of assessment. In: Language Teaching 42/4, 491-503.

Fulcher, G., Davidson, F., 2007. Language Testing and Assessment: An Advanced Resource Book. New York: Routledge.

Genesee, F., Upshur, J.A., 1996. Classroom-based evaluation in second language education. New York: Cambridge University Press.

Komorowska, H., 2002. Sprawdzanie umiejętności w nauce jezzyka obcego: kontrola, ocena, testowanie. Warszawa: Fraszka Edukacyjna.

Lantolf, J.P., 2009. Dynamic assessment: The dialectic integration of instruction and assessment. In: Language Teaching 42/3, 355-368.

Leung, C., 2005. Classroom teacher assessment of second language development: construct as practice. In: Hinkel, E. (ed.). Handbook of research in second language learning and teaching. Mahwah, NJ: Lawrence Earlbaum, 869-888.

Leung, C., Lewkowicz, J., 2006. Expanding Horizons and Unresolved Conundrums: Language Testing and Assessment. In: TESOL Quarterly 40/1, 211-234.

Llosa, L., 2011. Standards-based classroom assessments of English proficiency: A review of issues, current developments, and future directions for research. In: Language Testing 28/3, 367-382.

McNamara, T., Roeven, C., 2006. Language testing: the social dimension. Oxford: Blackwell Publishing.

Mok, J., 2011. A case study of students' perceptions of peer assessment in Hong Kong. In: ELT Journal 65/3, 230-239.

Piegzik, W., 2005. Ocenianie osiągnięć uczniowskich na lekcjach języków obcych. In: Języki Obce w Szkole 6/2005, 75-83.

Poehner, M.E., 2009. Group dynamic assessment: mediation for the L2 classroom. In: TESOL Quarterly 43/3, 471-491.

Rea-Dickins, P., 2004. Understanding teachers as agents of assessment. In: Language Testing 21/3, 249-258.

Rea-Dickins, P., 2006. Currents and eddies in the discourse on assessment: a learning-focused interpretation. In: International Journal of Applied Linguistics 16/2, 163-188.

Shohamy, E., Inbar, O., 2006. Assessment of advanced language proficiency: Why performance-based tasks? (CALPER Professional Development Document 0605). University Park, PA: The Pennsylvania State University, Center for Advanced Language Proficiency Education and Research.

Shohamy, E., Inbar-Lourie, O., Poehner, M., 2008. Investigating assessment perceptions and practices in the advanced foreign language classroom (Report No. 1108). University Park, PA: Center for Advanced Language Proficiency Education and Research.

Zawadzka, E., 2004. Nauczyciele języków obcych w dobie przemian. Kraków: Oficyna Wydawnicza "Impuls". 